\title{
23. Metabolism of Adipose Tissue in vitro
}

\author{
By A. Mirski, From the Laboratory of Pathological Physiology, \\ The Hebrew University, Jerusalem
}

(Received 26 January 1942)

It has been shown [Hoffman \& Wertheimèr, 1927; Tuerkischer \& Wertheimer, 1941] that glycogen accumulates in the adipose tissues of fasted animals which are placed on a carbohydrate-high diet. Glycogen appears in the adipose tissue of fasted rats soon after the first carbohydrate meal, but is transient and disappears 4 days later giving way to fat. It was suggested from this and from other experiments that glycogen could be transformed into fat by adipose tissue. Confirmation of this conclusion by experiments in vitro, which might throw further light on the question whether adipose tissue can form glycogen and build its fat from carbohydrate seemed desirable. Part I of this communication presents experiments on the breakdown and synthesis of glycogen by adipose tissue; Part II summarizes experiments on the respiratory activity and respiration quotient of normal and hunger-fat in the absence and presence of carbohydrates.

\section{Methods}

Animals. In the enzyme experiments adipose tissue from ordinary rats, but in a few cases also rabbit, dog and human adipose tissues, were used. Both brown interscapulary and white ordinary fat have been tested. In measurements of respiration, the fat tissue used was from rats which had been maintained for about a week to a loss of $20 \%$ body weight on a starvation diet. Glycogen-fat was obtained from rats, which after being fasted received a meal rich in carbohydrate [Tuerkischer \& Wertheimer, 1942].

Adipose brei. Adipose brei was prepared by removing adipose tissue from the freshly killed animal and macerating with scissors. The tissue was kept cold meanwhile on ice. For respiration experiments the fat tissue was suspended in phosphate-Ringer to wash away the blood, dried on filter papers and then minced with scissors.

Adipose extract. Adipose extract was obtained by addition of 1.5 parts ice water to brei, shaking and centrifuging after 15-20 min.

Phosphorylase eluate. Phosphorylase was isolated from adipose extract according to the method used by Cori et al. [1939], by shaking extract with $\mathrm{Al}(\mathrm{OH})_{3} \mathrm{C} \gamma$, centrifuging, and after rinsing the sediment with cold water, eluting for $1 \mathrm{hr}$. at room temperature with 0.5 vol. of $0.25 M$ solution of $\mathrm{Na}$ glycerophosphate.

Substrates. The glycogen used was prepared from rabbit liver by the method of Somogyi [1934], and was free of $\mathrm{N}$ and $\mathrm{P}$.

Glucose-1-phosphate (Cori ester =c.E.) was used in the form of the dipotassium salt and was prepared enzymically from starch by the action of potato juice as described by Hanes [1940].

Muscle adenylic acid was obtained from Laocoon Comp., Lwow.

Analytical methods. Glycogen was determined by the method of Pflüger. Phosphate was measured according to Fiske \& Subbarow [1925].

Cori ester was measured by hydrolysis at $100^{\circ}$ in $\mathrm{N} \mathrm{H}_{2} \mathrm{SO}_{4}$ for $10 \mathrm{~min}$. The increase in inorganic phosphate was assumed to be the equivalent of the amount of c.E. Labile esters other than c.E. were nọt present in our mixtures.

Amylase activity was followed $(a)$ by determination of the glycogen loss, $(b)$ by estimation of the increase in reducing power in deproteinized solutions using the reagent described by Somogyi [1937] for sugars with low reducing power. 
Glucose in the mixture was determined according to the method of Somogyi for glucose assay in the presence of maltose.

The products of the action on glycogen were determined by fractional precipitation with different mixtures of alcohol and ether as described by Somogyi [1938].

Lactic acid was determined according to Lieb \& Zacherl [1932], and pyruvic acid according to Clift \& Cook [1932].

The $\mathrm{O}_{2}$ consumption and the respiratory quotient (R.Q.) of adipose tissue were measured by the direct method of Warburg; the latter is therefore the apparent R.Q.

Technique. Mixtures were incubated at a temperature of $37^{\circ}$ and shaken except at sampling. Glycogen synthesis was effected at room temperature.

\section{RESULTS}

\section{Breakdown and synthesis of glycogen by adipose tissue in vitro}

(a) Phosphorylysis of glycogen by adipose tissue (Table 1). Adipose fat, as may be seen from Table 3, shows considerable amylase activity. This enzyme accounts for the main loss of glycogen from adipose tissue or from a mixture of adipose extract and glycogen solution.

Table 1. Phosphorylysis of glycogen by brei and aqueous extract of adipose tissue

The indicated quantities of adipose brei were shaken with $2 \mathrm{ml}$. phosphate buffer $p \mathrm{H} \mathbf{7 \cdot 2}$ containing $5 \%$ glycogen and $M / 20 \mathrm{NaF}$ at $37^{\circ}$. Enzyme action was stopped by addition of $1 \mathrm{ml} .25 \%$ trichloroacetic acid.

\begin{tabular}{|c|c|c|c|c|c|c|}
\hline \multirow[b]{2}{*}{ Kind of fat } & \multirow[b]{2}{*}{$\begin{array}{l}\text { Weight of } \\
\text { fat, g. }\end{array}$} & \multirow[b]{2}{*}{$\begin{array}{l}\text { Initial amount } \\
\text { of } \mathrm{P}_{2} \mathrm{O}_{5}, \mathrm{mg} \text {. }\end{array}$} & \multicolumn{2}{|c|}{ Decrease of $\mathrm{P}_{2} \mathrm{O}_{5}, \mathrm{mg}$. } & \multicolumn{2}{|c|}{$\begin{array}{l}\text { Inorganic phosphate after } \\
10 \text { min. hydrolysis } N \mathrm{HCl}\end{array}$} \\
\hline & & & $\begin{array}{l}\text { After } \\
2 \mathrm{hr} \text {. }\end{array}$ & $\begin{array}{l}\text { After } \\
3 \mathrm{hr} \text {. }\end{array}$ & $\begin{array}{l}\text { At beginning } \\
\text { of incubation }\end{array}$ & $\begin{array}{l}\text { After } \\
3 \mathrm{hr} \text {. }\end{array}$ \\
\hline $\begin{array}{c}\text { White fat of rats } \\
\text {, }\end{array}$ & $\begin{array}{l}0 \cdot 5 \\
0 \cdot 6\end{array}$ & $\begin{array}{l}5 \cdot 06 \\
4 \cdot 90\end{array}$ & $\underline{0.56}$ & $\begin{array}{l}0 \cdot 62 \\
0 \cdot 46\end{array}$ & $\begin{array}{l}5 \cdot 00 \\
4 \cdot 90\end{array}$ & $\begin{array}{l}5 \cdot 04 \\
4 \cdot 84\end{array}$ \\
\hline Brown fat & $0 \cdot 3$ & $5 \cdot 18$ & $1 \cdot 46$ & 一 & - & - \\
\hline \multicolumn{7}{|c|}{ Experiments with aqueous extract (1-0.6 ml. extract and $2 \mathrm{ml}$. buffer) } \\
\hline & ml. & - & $2 \mathrm{hr}$. & $4 \mathrm{hr}$. & & \\
\hline White fat & $1 \cdot 0$ & $5 \cdot 06$ & 0 & 0 & & \\
\hline Brown fat & $0 \cdot 6$ & $4 \cdot 78$ & $0 \cdot 44$ & - & . & \\
\hline
\end{tabular}

Using rat adipose brei and glycogen concentrations up to $1 \%$ no significant decrease in inorganic $\mathrm{P}$ could be demonstrated in the presence of $\mathrm{NaF}$ : A definite decrease was only noticed, as may be seen in Table 1 , when a glycogen concentration of 4-5\% was employed. It may be noted that Gill \& Lehmann [1939] state that amylase inhibits the phosphorylysis of glycogen, but that the inhibitory effect can be largely abolished by the use of a large excess of glycogen. It may be concluded that the adipose tissue contains phosphorylase.

The disappearance of inorganic $\mathbf{P}$ under the conditions of this experiment is completely accounted for as $\mathrm{P}$ liberated by hydrolysis of the trichloroacetic acid filtrates with $N \mathrm{HCl}$ for $10 \mathrm{~min}$. at $100^{\circ}$. The phosphoric ester formed under the conditions of this experiment is identified by this evidence as glucose-1-phosphate.

Different results are obtained using muscle or liver tissue. In brei or extract of muscle, all phosphorylysed glycogen is converted into hexosediphosphate and glyceric acid phosphate; in liver, hexose-6-phosphate is obtained. The different behaviour of adipose tissue must be attributed to the absence from this tissue of phosphoglucomutase (see Table 2). The same circumstance also provides a partial explanation of the low phosphorylase activity of adipose tissue. In the absence of phosphoglucomutase the equilibrium, glycogen $\rightleftarrows$ c.E., which has been defined by Cori \& Cori [1940] at $90 \%$ inorganic phosphate and $10 \%$ c.E. phosphate must be expected to be attained at an early stage. 
Extract of ordinary adipose tissue, in contrast to adipose brei, failed to effect a decrease of inorganic phosphate within an incubation time up to $4 \mathrm{hr}$.

Brown interscapulary fat of rats differs in activity from white adipose tissue, and phosphorylyses glycogen with a markedly greater velocity. Calculated to fresh weight its activity equals one-half that of liver. Both extract and brei of interscapulary fat were active.

(b) Phósphoglucomutase and phosphatase. Muscle and liver brei and their extracts rapidly convert glucose-1-phosphate into glucose-6-phosphate with the aid of phosphoglucomutase. In liver a phosphatase liberates inorganic phosphate from c.E. either directly or after conversion of the latter into Robison ester (R.E.). In view of the results reported under $(a)$ it seemed important to ascertain whether adipose tissue too could convert glucose-1-phosphate in this manner (Table 2).

\section{Table 2. Breakdown of Cori ester by adipose tissue}

1.0 g. adipose brei or $1.0 \mathrm{ml}$. adipose extract were shaken with bicarbonate buffer $p \mathrm{H} 7 \cdot 2$ containing $20 \mathrm{mg}$. dipotassium salt of glucose-1-phosphate in the presence and absence of $M / 20 \mathrm{NaF}$ at $37^{\circ}$. Enzyme action was stopped by addition of $0.5 \mathrm{ml} .25 \%$ trichloroacetic acid.

\begin{tabular}{|c|c|c|c|c|c|c|c|}
\hline & & Inorganic ph & hate, & $\mathrm{P}_{2} \mathrm{O}_{5}$ & Inorganic pho & $\begin{array}{l}\text { ate af } \\
\text { lysis }\end{array}$ & $\min$. \\
\hline Kind of fat & $\begin{array}{l}\text { Conc. of } \\
\mathrm{NaF}\end{array}$ & $\begin{array}{l}\text { At beginning of } \\
\text { incubation }\end{array}$ & $\begin{array}{l}\text { After } \\
2 \mathrm{hr} \text {. }\end{array}$ & $\begin{array}{l}\text { After } \\
5 \mathrm{hr} .\end{array}$ & $\begin{array}{l}\text { At beginning of } \\
\text { incubation }\end{array}$ & $\begin{array}{l}\text { After } \\
2 \mathrm{hr} \text {. }\end{array}$ & $\begin{array}{c}\text { After } \\
5 \mathrm{hr} .\end{array}$ \\
\hline White & $M / 20$ & $0 \cdot 9$ & 0.91 & 0.91 & $7 \cdot 0$ & 一 & $7 \cdot 90$ \\
\hline & 0 & 0.59 & - & $0 \cdot 63$ & - & - . & - \\
\hline Brown (0.45 g.) & $M / 20$ & 1.9 & $1 \cdot \tilde{0} 0$ & - & $7 \cdot 90$ & $5 \cdot 95$ & 一 \\
\hline & ${ }^{*}$ & $\operatorname{Exp}$ & ments & extract & & . & , \\
\hline White & $\begin{array}{c}M / 20 \\
0\end{array}$ & $\begin{array}{l}0.90 \\
1 \cdot 55\end{array}$ & $\begin{array}{l}0.8 \\
1 \cdot 25\end{array}$ & - & $\begin{array}{l}7 \cdot 90 \\
-\end{array}$ & $\begin{array}{c}7 \cdot 90 \\
-\end{array}$ & - \\
\hline
\end{tabular}

Table 2 shows clearly that brei and extract of white adipose tissue do not contain even traces of glucomutase. Both in the presence and absence of NaF, c.E. added to brei or extract remains unchanged even after prolonged incubation periods.

Brei of brown adipose tissue in contradistinction to white adipose tissue converts C.E. into R.E. Brown interscapulary fat must therefore be concluded to contain phosphoglucomutase. This finding offers a ready explanation of the greater ability of brown fat to esterify inorganic phosphate on incubation with glycogen in the presence of $\mathrm{NaF}$.

(c) Synthesis of glycogen from glucose-1-phosphate. The Na glycerophosphate eluate of adipose tissue extract prepared as prescribed by Cori was found still to contain amylase. Demonstration of ability to synthesize glycogen is made difficult by this circumstance, as glycogen formed in this preparation would be removed by diastatic action. The eluate alone was found to be inactive towards c.E., but liberated inorganic phosphate from this substrate when glycogen and adenylic acid of muscle were added [cf. Cori et al. 1939]. Under suitable conditions (high concentration of c.E., reduced concentration of glycogen permitting increased accuracy in glycogen determination) it has been possible to demonstrate an increase of glycogen in these mixtures equal to $50 \%$ or more of the amount of glycogen initially present. Adipose tissue does not contain a phosphatase which is capable of acting on Cori ester. Moreover, it is most unlikely that such a phosphatase, even if present in the tissue, would be recovered in the eluate. It seems proper to conclude therefore that the amount of c.E. decomposed by the eluate with liberation of inorganic phosphate is equivalent to the amount of glycogen formed but at the same time in large part removed. In experiments with rat liver a similar discrepancy between the amount of glycogen accumulated and the amount of phosphate liberated, has been encountered. In rabbit liver, on the other hand, an exact equivalence between the amount of glycogen found and the amount of Cori ester used up appears to be the rule. It has been pointed out by Cori et al. [1939] that rat liver in contrast to rabbit liver contains much amylase. 
Table 3 indicates the course of synthesis of glycogen from c.e. by an enzyme solution prepared from white adipose tissue of young and old rats, of old rabbits, of 1-day-old rabbits and of human fat. The figures for synthesis are calculated from the amount of inorganic phosphate liberated. The increase of glycogen over the initial value is also given. The experiments summarized in Table 3 show that the activity of eluates from adipose tissue of young animals is greater than that of the eluates of adipose tissue from adult ones.

\section{Table 3. Synthesis of glycogen from Cori ester by phosphorylase eluate of adipose tissue}

To $2 / 3 \mathrm{ml}$. eluate was added $1 / 3 \mathrm{ml}$. of a solution in $N / 10 \mathrm{H}_{2} \mathrm{SO}_{4}$ made to give a final concentration of 10-20 mg. dipotassium salt of glucose-1-phosphate, $0 \cdot 4 \mathrm{mg}$. muscle adenylic acid, and 100-500 mg. per $100 \mathrm{ml}$. glycogen per $\mathrm{ml}$., at $p H \mathbf{7 \cdot 0}$. Incubation was at room temperature.

\begin{tabular}{|c|c|c|c|c|c|c|c|}
\hline \multirow[b]{2}{*}{ Kind of fat } & \multirow{2}{*}{$\begin{array}{l}\text { Conc. of } \\
\text { glycogen in } \\
\text { mg. per } \\
100 \mathrm{ml} .\end{array}$} & \multirow{2}{*}{$\begin{array}{l}\text { Amount of } \\
\text { dipotassium } \\
\text { salt of c.E. }\end{array}$} & \multicolumn{5}{|c|}{$\begin{array}{l}\text { \% glucose-1-phosphate converted into glycogen, } \\
\text { calc. from the amount of inorganic phosphate } \\
\text { formed after min. }\end{array}$} \\
\hline & & & 15 & 30 & 60 & 90 & $120^{\circ}$ \\
\hline White fat of young rats $(a)$ & 500 & 10 & $11 \cdot 6$ & $24 \cdot 2$ & $32 \cdot 8$ & $34 \cdot 4$ & - \\
\hline & 500 & 10 & $11 \cdot 5$ & $18 \cdot 4$ & $35 \cdot 2$ & $46 \cdot 0$ & $49 \cdot 0$ \\
\hline White fat of old rats $(b)$ & 500 & 10 & $4 \cdot 0$ & $9 \cdot 5$ & $30 \cdot 0$ & - & - \\
\hline Rabbit fat & 500 & 10 & $3 \cdot 0$ & $7 \cdot 0$ & $13 \cdot 0$ & - & - \\
\hline Embryonic rabbits fat $(c)$ & 500 & 10 & - & $36 \cdot 2$ & $56 \cdot 0$ & - & - \\
\hline \multirow[t]{3}{*}{ Human fat } & 500 & 10 & $3 \cdot 3$ & 一 & - & $16 \cdot 0$ & $20 \cdot 4$ \\
\hline & \multirow{2}{*}{. } & \multirow[t]{2}{*}{. } & \multirow{2}{*}{\multicolumn{2}{|c|}{$\begin{array}{l}\text { \% c.e. converted } \\
\text { into glycogen calcu- } \\
\text { lated as above after } \\
\text { min. }\end{array}$}} & \multicolumn{3}{|c|}{$\begin{array}{l}\text { Increase of glycogen amoun } \\
\text { over initial value after min. }\end{array}$} \\
\hline & & & & & 0 (initis & 30 & 60 \\
\hline White fat of rats & $\begin{array}{l}100 \\
100\end{array}$ & $\begin{array}{l}20 \\
20\end{array}$ & $\begin{array}{l}7 \cdot 5 \\
5 \cdot 0\end{array}$ & $\begin{array}{r}10 \cdot 5 \\
8 \cdot 1\end{array}$ & $\begin{array}{l}0.95 \\
0.93\end{array}$ & $\begin{array}{c}0.45 \\
-\end{array}$ & $\begin{array}{l}0.52 \\
0.70\end{array}$ \\
\hline
\end{tabular}

(a) Young rats of 50-80 g. body wt. (b) Ọld rats of 180-250 g. body wt. (c) One-day-old rabbits.

A singular result was obtained with adipose tissue of 1-day-old rabbits. Such tissue is brown as is the interscapular fat of rats. The activity of eluates from embryonic rabbit adipose tissue greatly exceeded that of eluates from other investigated kinds of fat tissue. The most active adipose tissue is always the brown adipose tissue. Eluates from adult rabbits and human white adipose tissue are roughly of the same small activity as that of adult rats adipose tissue.

The polysaccharide which adipose tissue/enzyme forms from c.E. differs in iodine reaction from glycogen. Iodine gives with our polysaccharide a reddish blue colour similar to that found with the polysaccharide formed by heart enzyme [Cori et al. 1939].

(d) Amylase and the products of its activity. As has been mentioned, adipose tissue contains an active amylase; on incubation of adipose brei or extract with glycogen solution at $p \mathrm{H} 7.2$ and $37^{\circ}$ in phosphate buffer the amount of glycogen which disappears is far in excess of that accounted for by phosphorylysis. The reducing power of the incubated mixture is considerably less than is expected on the assumption that maltose or glucose is the product, formed by amylase activity. ' On hydrolysis in $\mathrm{N} \mathrm{H}_{2} \mathrm{SO}_{4}$ for $1 \mathrm{hr}$., the amount of glucose liberated is equal to that obtained on hydrolysis before incubation. Detailed analysis of the reaction products, using the fractionation method of Somogyi [1938] and determination of the ratio of reducing power before hydrolysis to reducing power after hydrolysis in the various fractions, showed that the reaction products consist of a mixture of low polysaccharides, mainly trisaccharides, and only a small amount (5\%). of glucose and maltose (Tables 4 and 5). 
Table 4. Glycogen cleavage by fat extract (amylolysis)

Fat extract obtained from a mixture of one part fat brei and two parts water. 1 vol. of glycogen solution in phosphate-Ringer was added to 2 vol. of the extract.

\begin{tabular}{|c|c|c|c|c|c|c|c|}
\hline \multirow[b]{2}{*}{$\begin{array}{l}\text { Vol. of extract } \\
\text { in ml. }\end{array}$} & \multirow[b]{2}{*}{$\begin{array}{c}\text { Initial } \\
\text { glycogen } \\
\text { mg. }\end{array}$} & \multirow[b]{2}{*}{$\begin{array}{c}\text { Incuba- } \\
\text { tion time } \\
\text { hr. }\end{array}$} & \multirow{2}{*}{$\begin{array}{l}\text { Glycogen } \\
\text { after } \\
\text { incubation } \\
\text { mg. }\end{array}$} & \multicolumn{2}{|c|}{ Reducing power* of filtrate } & \multirow{2}{*}{\multicolumn{2}{|c|}{ Ratio $b / a$}} \\
\hline & & & & $\begin{array}{l}\text { (a) Before } \\
\text { hydrolysis }\end{array}$ & $\begin{array}{c}\text { (b) After } \\
\text { hydrolysis }\end{array}$ & & \\
\hline \multirow[t]{3}{*}{$\begin{array}{l}1 \\
10 \\
15 \\
20\end{array}$} & $\begin{array}{c}16 \cdot 5 \\
150 \\
300 \\
450\end{array}$ & $\begin{array}{r}3 \\
\mathbf{3} \\
20 \\
20\end{array}$ & $\begin{array}{c}5 \\
56 \cdot 25 \\
0 \\
\text { Traces }\end{array}$ & $\begin{array}{c}2 \cdot 44 \\
48 \\
81 \cdot 2 \\
123\end{array}$ & $\begin{array}{l}\quad 9 \cdot 61 \\
154 \cdot 5 \\
305 \\
400\end{array}$ & & $\begin{array}{l}90 \\
25 \\
25\end{array}$ \\
\hline & & & & & . & Total car & ohydrate \\
\hline & & & & & & $\begin{array}{l}\text { Before } \\
\text { incuba- } \\
\text { tion }\end{array}$ & $\begin{array}{c}\text { After } \\
\text { incuba- } \\
\text { tion }\end{array}$ \\
\hline $\begin{array}{l}0.5 \mathrm{~g} . \text { fat brei } \\
\text { in } 2 \mathrm{ml} \text {. Ringer }\end{array}$ & $4 \cdot 03$ & 1.5 & $1 \cdot 74$ & $0 \cdot 357$ & $4 \cdot 55$ & $4 \cdot 94$ & $4 \cdot 76$ \\
\hline & & & * Calc. & se. & & & \\
\hline
\end{tabular}

Table 5. Fractionation of low polysaccharide products according to Somogyi (reducing power calculated as glucose)

(a)

Fraction

1. Precipit. by : $60 \%$ alc.

2. $\quad 9$ alc. : 3 ether

3. $\quad 9$ alc. $: 10$ ether

4. $\quad 9$ alc. : 20 ether

5. Supernatant liquid
Reducing power
before hydrolysis

54
125
$27 \cdot 25$
$37 \cdot 65$
$38 \cdot 5$

(b)

Reducing power after hydrolysis

$\begin{array}{cl}276 & 5 \cdot 1 \\ \cdot 394 & 3 \cdot 15 \\ 70 \cdot 0 & 2 \cdot 56 \\ 67 \cdot 5 & 1 \cdot 79 \\ 51 \cdot 5 & 1 \cdot 34\end{array}$

\section{Respiration and R.Q. of adipose tissue}

The experiments considered below were each carried out with $0 \cdot 3 \mathrm{~g}$. fat brei in $2 \mathrm{ml}$. phosphate-Ringer. The time between removal of the fat from the body and the actual beginning of respiration measurement was about $\frac{1}{2} \mathrm{hr}$. Total values obtained were always rather low, and it was therefore of some importance to correct the result for the amount of $\mathrm{CO}_{2}$ initially present. All data given refer to $0.3 \mathrm{~g}$. fresh weight of adipose tissue per $\mathrm{hr}$. Recalculation to a basis of fat-free dry matter, being clearly open to criticism, was not attempted. 'Reference to a basis of $\mathrm{N}$ content was likewise rejected, as the $\mathrm{N}$ of adipose tissue may show appreciable variations. As absolute values were not needed, reference to a fresh-weight basis was regarded as satisfactory.

Considerable fluctuations were found in different experiments of the same series. This was partly due no doubt to differences in the fat content of different lots of adipose tissue.

(a) Respiration and R.Q. of hunger-fat and glycogen-fat in Ringer solution. Hungerfat. The $\mathrm{O}_{2}$ consumption of hunger-fat fluctuated between 24 and $45 \mu \mathrm{l}$. and in 22 experiments averaged $37 \mu \mathrm{l}$. Corresponding fluctuations were observed in the R.Q., which ranged between 0.42 and 0.78 and averaged 0.64 (Table 6).

Table 6. Glycogen concentration, $\mathrm{O}_{2}$ consumption and R.Q. of different kinds of fat

\begin{tabular}{|c|c|c|c|c|}
\hline No. of exp. & Kind of fat & Glycogen in fat $\%$ & Resp. rate & R.Q. \\
\hline 22 & Hunger-fat & - & $37 \cdot$ & 0.643 \\
\hline 21 & Glycogen-fat & $\begin{array}{l}\text { Before } 0.35 \\
\text { After } \quad 0.07\end{array}$ & 55 & $1 \cdot 050$ \\
\hline 7 & $\begin{array}{l}\text { Glycogen-fat with addition of } \\
M / 50 \text { hexoate or butyrate }\end{array}$ & $\begin{array}{l}\text { Before } 0 \cdot 33 \\
\text { After } 0 \cdot 11\end{array}$ & 50 & $\begin{array}{l}0 \cdot 74 \\
.\end{array}$ \\
\hline
\end{tabular}


The low R.Q. values are most easily explained by the assumption of an incomplete combustion of fatty acids. Acetone bodies were not found however. Individual cases in which a higher R.Q. was noted may be explained by the parallel combustion of sugar traces. In such cases the quotient drops to lower values in the 2 nd hour of the measurements. Addition of $N / 1000-N / 2000 \mathrm{KCN}$ generally inhibits respiration by about $75 \%$. Monoiodoacetate affects the respiratory quotient of glycogen adipose tissue only when respiration itself becomes affected. Exposure to $100^{\circ}$ for $10 \mathrm{~min}$. suppresses the respiration of adipose tissue almost completely.

If to a suspension of starvatipn adipose tissue $0.25 \%$ glucose is added, an appreciable increase in the R.Q. is uniformly noted. Addition of glycogen in equal concentration to the suspension of fat tissue is without effect on the metabolism. On addition of pyruvate, $\mathrm{O}_{2}$. consumption is increased and the R.Q. rises to $1 \cdot 25$, i.e. to values which correspond to an exclusive pyruvate respiration. Addition of $\mathrm{Na}$ lactate, on the other hand, is without effect (Table 7). During the incubation time of the Warburg measurements, pyruvate was

\begin{tabular}{|c|c|c|c|}
\hline No. of exp. & Addition & Resp. rate & R.Q. \\
\hline $\begin{array}{r}10 \\
9 \\
7\end{array}$ & $\begin{array}{l}\quad 0 \\
0.25 \% \text { glucose } \\
0.25 \% \text { glycogen }\end{array}$ & $\begin{array}{l}41 \cdot 7 \\
46 \cdot 6 \\
33 \cdot 4\end{array}$ & $\begin{array}{l}0 \cdot 62 \\
0 \cdot 79 \\
0 \cdot 60\end{array}$ \\
\hline $\begin{array}{l}8 \\
8 \\
5\end{array}$ & $\begin{array}{l}0 \\
M / 50 \text { pyruvate } \\
M / 50 \text { lactate }\end{array}$ & $\begin{array}{l}38 \cdot 7 \\
51 \cdot 0 \\
33 \cdot 4\end{array}$ & $\begin{array}{l}0.633 \\
1.25 \\
0.68\end{array}$ \\
\hline
\end{tabular}

found to disappear in small amounts, but the concentration of lactate remained practically unchanged. In one experiment, for instance, the concentration of pyruvate decreased from an initial value of 3.97 to $3.64 \mathrm{mg}$. after $1 \mathrm{hr}$., and to $3.48 \mathrm{mg}$. after $3 \mathrm{hr}$. In a second experiment the concentration of pyruvate was decreased from the same initial concentration to $3.34 \mathrm{mg}$. after $1 \mathrm{hr}$. Lactic acid, on the other hand, was found in one experiment to be $3.64 \mathrm{mg}$. at the outset and $3.82 \mathrm{mg}$. after $1 \mathrm{hr}$., and in a second experiment $3.82 \mathrm{mg}$. at the outset and $3 \cdot 74 \mathrm{mg}$. after $2 \mathrm{hr}$.

Glycogen-fat. The $\mathrm{O}_{2}$ consumption of glycogen-fat is considerably increased as compared with starvation fat ( $55 \mu \mathrm{l}$. as against $37 \mu \mathrm{l}$.) and its R.Q. is higher. Values exceeding unity were obtained in 10 out of the 20 experiments performed, the remainder ranging between 0.90 and 1.0 except for a single case in which a R.Q. of 0.75 was recorded. It should be noted that the above high quotient values are only found during the lst hour of incubation; in the 2nd and later hours, the quotient values show a rapid fall. In one typical case, the R.Q. was $1 \cdot 14$ during the lst hour, 0.89 during the 2 nd hour and 0.83 during the 3rd hour. In a second case, the values found were 1.28 during the lst hour, and 0.83 during the $3 \mathrm{rd}$ hour. The increased respiratory quotient of glycogen-fat is specifically depressed, however, by addition of $M / 50$ hexoate, butyrate, or propionate.

The amount of lactic acid produced in glycogen-fat is remarkably small. $1 \mathrm{~g}$. of glycogenfat incubated for $3 \mathrm{hr}$. produced no more than $0.8 \mathrm{mg}$. lactic acid under anaerobic conditions, and only $0.5 \mathrm{mg}$. lactic acid under aerobic conditions. Such amounts may be regarded as functionally negligible. The amount of lactic acid formed under aerobic and anaerobic conditions from added glycogen by starvation adipose tissue is likewise negligible. On glucose addition, on the other hand, an average of fully $1 \mathrm{mg}$. of lactic acid was formed in five experiments under anaerobic but otherwise similar conditions.

Calculations from the respiration values show that the total amount of glycogen oxidised is very small. During incubation in the Warburg apparatus the glycogen is largely decomposed by adipose amylase. It seemed permissible to suppose that the observed drop in the respiratory quotient was due to the conversion of glycogen by amylase 
into non-fermentable products which cannot be utilized by adipose tissue. By a fortunate coincidence an adipose tissue was found which contained a considerable amount of glycogen and was unusually poor in diastase activity. Adipose tissue of this kind is constituted by the mesenteric adipose tissue of dogs which after being fasted for 8 days are placed for 1-2 days on a diet high in carbohydrates. The R:Q. of this tissue generally remains greater than 1 throughout the lst hour of incubation (Table 8) but falls subsequently. Nevertheless,' the amount of glycogen broken down even after 2-3 hr. incubation was hardly greater than that accounted for by the respiration values. In one typical experiment (no. 3), for instance, the R.'Q. for the 1st, 2nd and 3rd hours respectively were 1.14, 0.89 and 0.83 . The amount of glycogen found after $3 \mathrm{hr}$. incubation -was still $0.77 \%$ as against an initial concentration of $1.00 \%$. It is therefore necessary to ascribe the observed drop in R.Q. to the great lability in Krebs-Ringer milieu of an essential enzyme component.

Table 8. Respiration and R.Q. of dog mesenteric fat

\begin{tabular}{|c|c|c|c|c|c|c|}
\hline No. & $\begin{array}{c}\text { Glycogen } \\
\text { initial value } \\
\%\end{array}$ & $\begin{array}{c}\text { Glycogen } \\
\text { after } 1 \mathrm{hr} . \\
\% / \Omega\end{array}$ & $\begin{array}{c}\text { Glycogen } \\
\text { after } 2 \text { hr. } \\
\%\end{array}$ & $\begin{array}{c}\text { Glycogen } \\
\text { after } 3 \mathrm{hr} \text {. } \\
\%\end{array}$ & $\mu \mathrm{l} . \mathrm{O}_{2} / 0 \cdot 3 \mathrm{~g} . / \mathrm{hr} . *$ & R.Q.* \\
\hline 1 & 1.08 & 0.916 & - & - & $101 \cdot 5$ & 0.95 \\
\hline 2 & 0.85 & 0.69 & 0.55 & - & 87 & $1 \cdot 28$ \\
\hline 3 & 1.00 & 0.91 & 0.80 & $0 \cdot 77$ & 95 & $1 \cdot 14$ \\
\hline 4 & 0.60 & 0.495 & $0 \cdot 44$ & - & $48 \cdot 5$ & $1 \cdot 08$ \\
\hline Cotal carbo- & $0 \cdot 66$ & $0 \cdot 60$ & $0 \cdot 54)$ & & & \\
\hline & & & * 1st hour & & $\cdot$ & \\
\hline
\end{tabular}

(b) Respiration and R.Q. of adipose tissue in serum. The question arose whether the labile path of breakdown which entails an increase in the R.Q. might be better preserved under more nearly physiological experimental conditions. Previous experience suggested the advisability of testing the effect of serum as the medium. Accordingly, adipose tissue was suspended in rabbit serum as prescribed by Warren [1940]. Under the conditions selected glycogen-fat showed a markedly increased rate of $\mathrm{O}_{2}$ consumption and a quotient which far exceeded 1 . The average $\mathrm{O}_{2}$ consumption found in 10 experiments was 115 ; the average R.Q. found in the same series was $1 \cdot 27$. Under the conditions of these experiments moreover, the enhanced R.Q. is maintained for many hours, and where the initial R.Q. is relatively low it may actually increase during incubation. Typical experiments illustrating these results are presented below (Table 9).

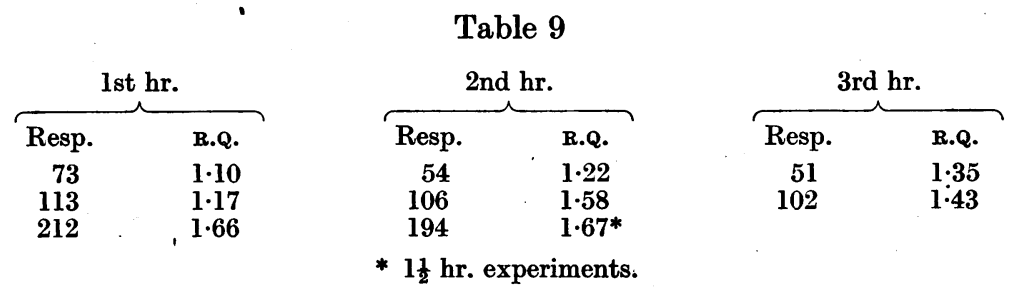

With hunger-fat also, the serum medium was found to produce an enhanced respiration rate and an increased R.Q. which frequently rose during incubation to values greater than unity. When glucose $(0.3 \%)$ was added to serum, the R.Q. exceeded unity in the first hours of the measurements (Table 10).

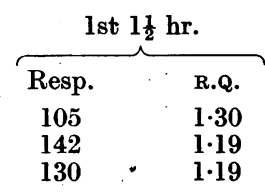

Table 10

\begin{tabular}{|c|c|}
\hline Resp. & R.Q. \\
\hline $\begin{array}{r}87 \\
112\end{array}$ & $\begin{array}{l}1 \cdot 29 \\
1 \cdot 30\end{array}$ \\
\hline 120 & $1 \cdot 38$ \\
\hline
\end{tabular}


The sugar concentration in serum gradually decreases during incubation. A series of experiments on hunger-fat was carried out using serum which had been treated with yeast to remove glucose and then rendered free of added yeast, by centrifuging and filtration through a Berkfeld filter. The average values of 8 such experiments in serum without glucose are tabulated below:

\begin{tabular}{|c|c|c|}
\hline $\mathrm{Hr}$. & Resp. & R.Q. \\
\hline $\begin{array}{l}\text { 1st } \\
\text { 2nd }\end{array}$ & $\begin{array}{l}58 \\
53\end{array}$ & $\begin{array}{l}0.78 \\
0.74\end{array}$ \\
\hline $3 \mathrm{rd}$ & 47 & 0.72 \\
\hline
\end{tabular}

It will be seen that the values found under these conditions are greater than are obtained in Ringer, but that the increase noted is of an order which might be due to the variation of the medium. On prolonged incubation, the values show a gradual decrease.

\section{Discussion}

The phosphorylysis of glycogen by adipose brei and the separation of an enzyme solution from adipase tissue which catalyses the synthesis of glycogen from c.E. shows that this tissue can form and break down glycogen. Adipose tissue is not therefore merely a passive source of stored fat as has hitherto been supposed, but an active organ with a specific carbohydrate metabolism.

The phosphorylytic breakdown path followed in adipose tissue is different from that of muscle and liver. Adipose tissue lacks phosphoglucomutase which converts glucose-1phosphate into glucose-6-phosphate and also lacks the enzyme which converts c.e. into glucose. It seems likely therefore that the equilibrium glycogen $\rightleftarrows$ Cori ester is not a link in the lactic acid or glucose-forming reaction chains of adipose tissue.

It has been shown in experiments described under (II) above that adipose tissue is capable of converting glucose into lactic acid in vitro, and that some accumulation of lactic acid occurs when adipose tissue is incubated in the presence of its own glycogen. The latter phenomenon may be due to the formation by amylolysis of a small amount of glucose, during incubation. The possibility that phosphorylysis constitutes an intermediary reaction in the synthesis of fat from carbohydrates remains to be examined.

The main products of the action of adipose diastase in vitro appear to be low polysaccharides which are resistant to further action by adipose tissue. The question arises whether adipose diastase plays a significant part in the metabolism of adipose tissue. Cori et al. [1939] and Lee \& Richter [1939] have concluded that in liver amylase does not play a significant part in the formation of glucose (blood sugar).

A point of interest is the observed difference in enzyme content between ordinary white and brown interscapular adipose tissues of rats. Differences in vivo between brown and white adipose tissue have previously been noted [Tuerkischer \& Wertheimer, 1942]. Experiments described above show that brown fat, unlike ordinary white fat, contains phosphoglucomutase. Brown adipose tissue must therefore be grouped together with other tissues which follow the glycogen breakdown scheme suggested by Cori et al. [1939].

The experiments under (II) above, show that the respiration and R.Q. of hunger-fat in Krebs solution are very low. On the other hand, adipose tissue which has accumulated glycogen due to recovery feeding, uniformly shows relatively higher respiration values, and a R.Q. which is near to or greater than unity and under favourable conditions is uniformly greater than unity. In recovery feeding on a high-protein diet, glycogen is not deposited in the adipose tissue and the R.Q. remains at the original low value. An adipose R.Q. greater than 1 is only found, therefore, where the existence in adipose tissue of a process may be suspected whereby carbohydrate is converted into fat.

Scoz [1932] carried out Warburg manometric experiments on adipose tissue. An abstract of his paper indicates that this author obtained R.Q. values of 1 or ca. 1 with 
normal or hunger-fat suspended in phosphate-Ringer. The values indicated are so abnormally high as to be hard to reconcile with our own experiments. Initial values which were always greater than 1 were, however, found by Scoz after recovery feeding. Ruska \& Quast [1935] state that the R.Q. of adipose tissue is frequently high, and found both respiration and glycolysis to be particularly high when brown fat was used. Henle \& Szpingier [1936] found a R.Q. of 0.75 for normal fat and an increase over this figure when glucose and pyruvate were added.

If glycogen or lactate are added to hunger-fat in vitro no effect on the respiration rate or R.Q. is evident. On addition of glucose the R.Q. in Ringer medium rises but remains well below 1. A uniform increase of R.Q. to values near 1.25 is only obtained on addition of pyruvate. It might be thought, therefore, that pyruvate oxidation is the cause of the high R.Q. values shown by glycogen-fat. Pyruvate, however, could in no case be isolated from adipose tissue as a product of glycogen breakdown. The high R.Q. of glycogen-fat, moreover, could be specifically depressed to low values by addition of fatty acids such as hexoic and butyric acids which had no influence on pyruvate oxidation. It has been shown furthermore that the specific glycogen breakdown path involving a high R.Q. is unstable in Ringer solution.

The R.Q. and respiration rate of glycogen-fat in Ringer tend already to fall after $1 \mathrm{hr}$. incubation. This fall also takes place when, as in the case of mesenteric fat, adipose glycogen is still abundantly present. No decline of the high R.Q. of pyruvate oxidation occurs within this time. In serum, the R.Q. of pyruvate oxidation remains unchanged, whereas that of adipose glycogen suffers a marked increase. A direct relationship between pyruvate oxidation and the enhanced R.Q. of glycogen-fat must therefore be regarded as improbable.

If Krebs solution is replaced by serum the conditions for glycogen breakdown by adipose tissue become decidedly more favourable. In serum medium, the R.Q. values found are uniformly greater than 1 , and the high quotients are maintained for many hours, and may even show an increase. Under the same conditions, but never in the absence of serum, it could be demonstrated further that glucose breakdown too shows R.Q. values greater than 1, which are maintained for several hours.

The total amount of glycogen which disappears from glycogen-fat during the Warburg experiments is far greater than that fraction of the glycogen loss which can be related to the amount of $\mathrm{O}_{2}$ consumed $(0 \cdot 1-0 \cdot 2 \mathrm{mg}$. in 1-2 hr.). The major portion of the glycogen broken down is converted into stabilized polysaccharides 'which are of no immediate interest in the present connexion. Where the $\mathrm{O}_{2}$-consuming breakdown process is very slow, as in the experiments reported above, the isolation of intermediary or end-products of this breakdown is a task of extreme difficulty. The high R.Q. shows, however, that adipose glycogen or added glucose are converted by adipose tissue into products of low oxygen content, probably into fatty acids.

\section{SUMMARY}

Adipose tissue phosphorylyses glycogen. The product of glycogen phosphorylysis by adipose brei is Cori ester.

Ordinary white adipose tissue of rats lacks phosphoglucomutase. Brown interscapular adipose tissue of rats contains this enzyme.

An enzyme solution which synthesizes glycogen from glucose-1-phosphate is obtained from adipose tissue extract using the procedure worked out by Cori. There is a marked difference in synthetic activity between eluates of young and old animals. The greatest activity is found in eluates of embryonic fat tissue. With advancing age, the synthetic activity falls.

In addition to phesphorylase, adipose tissue contains amylase. In vitro the latter converts glycogen into low polysaccharides (trisaccharides) which are not fermentable. 
Only a small part of the total amount of glycogen broken down by diastase is accounted for as glùcose.

Respiration experiments with adipose tissue in vitro showed the following facts.

Hunger-fat suspended in phosphate-Ringer under specified conditions consumes oxygen at a variable rate. The average $\mathrm{O}_{2}$ consumption was $37 \mu \mathrm{l} . / \mathrm{hr} . / 0 \cdot 3 \mathrm{~g}$. of fresh tissue, the average R.Q. was 0.64 .

Glycogen-fat obtained after reçovery feeding shows an average rate of $\mathrm{O}_{2}$ consumption of $53 \mu \mathrm{l}$./hr. and an average R.Q. of.1.05. This heightened rate of $\mathrm{O}_{2}$ consumption and the high R.Q. were transient under the conditions of these experiments and tended to fall after 1-2 hr.

Addition of glucose to hunger-fat increased the average R.Q. to $0 \cdot 79$.

Addition of glycogen or lactic acid did not affect the R.Q. Addition of pyruvic acid increased the respiration rate to 51 and the R.Q. to 1·25.

In serum as medium, the $\mathrm{O}_{2}$ consumption and R.Q. values of hunger-fat are 55 and 0.78 respectively. With added glucose, the corresponding average values are 65 and $1 \cdot 15$.

Glycogen fat, in serum medium, produces an $\mathrm{O}_{2}$ consumption rate of 115 and a R.Q. of 1.27. In serum, the enhanced respiratory quotient of glycogen-fat is maintained for many hours and may even rise to $\mathbf{1 \cdot 6}$.

Only a small fraction of the glycogen lost during incubation in the Warburg experiments is accounted for by the amount of $\mathrm{O}_{2}$ consumed. The greater part of the glycogen loss is recoverable as non-fermentable tri- or polysaccharide.

The author is greatly indebted to Prof. E. Wertheimer for his interest and guidance in this investigation.

\section{REFERENCES}

Clift, F. P. \& Cook, R. P. [1932]. Biochem. J. 26, 1788.

Cori, G. T. \& Cori 'C. F. [1940]. J. biol. Chem. 135, 733.

Cori, G. T., Cori, C. F. \& Schmidt, G. [1939]. J. biol. Chem. 129, 629.

Fiske, C. H. \& Subbarow, Y. [1925]. J. biol. Chem. 66, 375.

Gill, P. M. \& Lehmann, H. [1939]. Biochem. J. 33, 1151.

Hanes, C. S. [1940]. Proc. roy. Soc. B, 129, 174.

Henle, W. \& Szpingier, G. [1936]. Arch. exp. Path. Pharmak. 180, 672.

Hoffmann, A. \& Wertheimer, E. [1927]. Pflüg. Arch. ges. Physiol. 217, 728.

Lee, M. \& Richter, D. [1939]. Biochem. J. 34, 353.

Lieb, H. \& Zacherl, M. K. [1932]. Hoppe-Seyl. Z. 211, 211.

Ruska, H. \& Quast, A. [1935]. Arch. exp. Path. Pharmak. 179, 217.

Scoz, G. [1932]. Arch. Sci. biol. Napoli, 17, 262 (cit. Ber. ges. Physiol. (1933), 70, 650).

Somogyi, M. [1934]. J. biol. Chem. 104, 246.

- [1937]. J. biol. Chem. 119, 741. [1938]. J. biol. Chem. 124, 179.

Tuerkischer, E. \& Wertheimer, E. [1942]. J. Physiol. 100, 385.

Warren, C. O. [1940]. Amer. J. Physiol. 128, 455. 